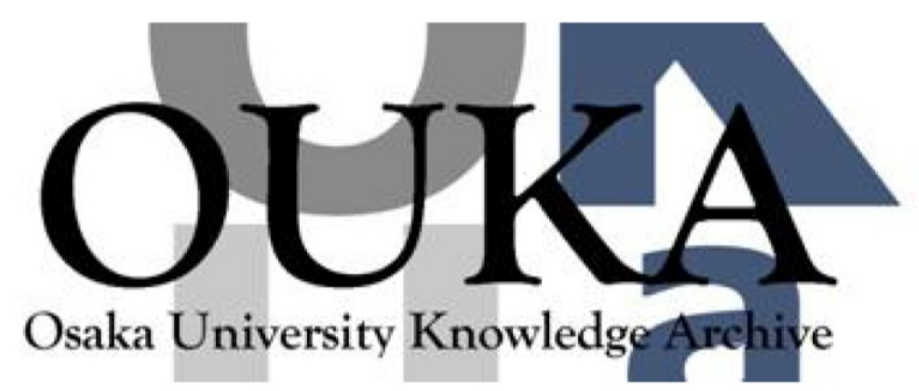

\begin{tabular}{|c|l|}
\hline Title & プログラム差分を用いたデバッグ支援手法DMET \\
\hline Author(s) & 松下，誠；寺口，正義；井上，克郎 \\
\hline Citation & $\begin{array}{l}\text { 電子情報通信学会論文誌D-I. J87-D-I(8) p. 815- } \\
\text { p. 823 }\end{array}$ \\
\hline Issue Date & 2004-08-01 \\
\hline oaire:version VoR \\
\hline URL & https://hdl. handle. net/11094/26583 \\
\hline rights & copyright $\odot 2004$ IEICE \\
\hline Note & \\
\hline
\end{tabular}

Osaka University Knowledge Archive : OUKA

https://ir. Library. osaka-u. ac. jp/

Osaka University 


\title{
プログラム差分を用いたデバッグ支援手法 DMET
}

\author{
松下 誠 ${ }^{\dagger a)}$ 寺口 正義 井上 克郎
}

Program-Delta Oriented Debugging Supporting Method DMET

Makoto MATSUSHITA ${ }^{\dagger a)}$, Masayoshi TERAGUTI ${ }^{\dagger \dagger}$, and Katsuro INOUE ${ }^{\dagger}$

あらまし 正常に機能することが事前に分かっているリビジョンと， 欠陥が含まれるリビジョンとの差分に着 目して自動的にテストを行うことで，俺の原因を特定する研究が行われている．しかし，テストのたびにソー スプログラムからソフトウェアを作成する必要があるため，非常に多くのテスト時間が必要となっていた．また， テスト作業にのみ重点が置かれており，デバッグ作業まで考慮されておらず，実用的とはいえなかった，光こで 本研究では, 従来よりもテスト実行時間を減らし , テストからデバッグまでの一連の流れを支援することで実際 のソフトウェア保守に利用可能なデバッグ手法 DMET の提案を行う．また，本手法の有効性を確認するため， DMET を用いた開発支援環境 DSUS の実装を行い，比較実験を行った，关の結果，DMET を用いることによ り,デバッグ時間全体を短縮できることが分かった．

キーワード リビジョン管理, 差分 , デバッグ

\section{1.まえがき}

ソフトウェアの保守とは, 本稼動中のソフトウェア の運用の継続を可能にするため, あるいは午れらを改 善するための工程である [3] . ソフトウェアにかかる全 費用のうち保守の占める割合は約 $80 \%$ にもぼり [4]， ソフトウェアに携わる人が費やす総時間の約 $65 \%$ が， 保守や先れに関連する作業に費やされている $[2]$.

ソフトウェア保守の本質を理解するために, Swanson はソフトウェア保守が必要となる要因を三つの基本的 な種類に分類している $[15]$.

・ ソフトウェア中のエラーに起因する欠陥

- ソフトウェアを取り巻く環境の変化

- ユーザや保守担当者の要求

更に, Swanson はこれらの基本的な要因に対応して 実行される保守活動を次のように定義している .

- 修正保守 : エラーの識別, 修正

- 適応保守 : 環境の変化に応じた修正

\footnotetext{
$\dagger$ 大阪大学大学院情報科学研究科, 豊中市

Graduate School of Engineering Science, Osaka University, 1-3 Machikaneyama-cho, Toyonaka-shi, 560-8531 Japan

†† IBM 東京基礎研究所, 大和市

Tokyo Research Laboratory, IBM Japan, Ltd., 1623-14 Shimotsuruma, Yamato-shi, 242-8502 Japan

a) E-mail: matusita@ist.osaka-u.ac.jp
}

- 完全化保守 : 性能の改善, 機能の変更や追加

一般的に , これらのソフトウェア保守活動の中では , 修正保守のための活動が一番多いと考えられがちであ る．しかし，1980 年代はじめに Lientz と Swanson に よって行われた調査によると，修正保守は保守作業の $20 \%$ にすきず，完全化保守が $55 \%$ を占めることが報告 されている $[11]$.

これらの保守活動においては, 既存のソフトウェア に対する多くの変更が発生する．しかし，ソフトウェ アに変更を加える際にエラーを発生させてしまう確率 は $50 \%$ から $80 \%$ の間であることが Hetzel の研究で示 されている $[7]$ ．したがって , 保守活動の $75 \%$ を占め る修正保守, 完全化保守において, ソフトウェアに変 更を加えた場合に，変更された部分の機能だけではな く変更されていない部分の機能に関しても動作確認が 必要となる.

開発の際に起きるこれらの動作確認のために，回帰 テスト [6], [10], [13] が広く用いられている.また，開発 されるソフトウェアはリビジョン管理システム $[1],[16]$ 等のソフトウェア管理システムを用いて管理されてい ることが多い．この 2 点に着目して，ソフトウェア管 理システムによって管理されているソフトウェアを対 象として，完全化保守を支援する研究がこれまで行わ れてきている [12], [17]．しかし，テストを実行する際 
に利用するテストツール [9] の設定を, 状況に応じて手 作業で行う必要がある . また , テスト後に行うデバッ グ作業に対する支援も十分とはいえない．

弚こで本研究では, 機能の変更や拡張を目的とした 完全化保守作業を対象とする .このような保守作業で は, 作業対象となる機能以外の部分も影響を受けて， テストで欠陌が検出されることがある．本論文では， このような欠陥の除去を効率良く行うために, 回帰テ ストを用いたデバッグ手法 DMET の提案を行う .

本手法では, まずプロダクトのリビジョンを順に取 り出し, テストツールを利用して自動的にテストを行 う. テストの結果, 次陥を出力するリビジョンと正常 に出力するリビジョンを発見した場合，このリビジョ ン間で行われた修正にエラーがあるとする．次に，こ の修正内容 (以下, 単に差分と呼ぶ) か現在のリビジョ ンにおいてどの部分に相当するかを調べる .この結果 を利用して, 利用者はデバッグを行い, 欠宿の修正を 行う. 欠陥を訂正した後, 弚の变更を古いリビジョン にも反映することで, 以降のテストに役立てる .

また，DMET の有効性を検証することを目的とし て，DMET を用いたデバッグ支援システムDSUS の 試作を行い，DSUS を用いた比較実験を行った .この 結果, DMET はテストからデバッグまでの一連の流 れを支援することができ，実際の保守においてデバッ グ作業時間を短縮できることが分かった。

\section{2. ソフトゥェア保守}

\section{1 保 守 作 業}

保守活動においてソフトウェアに変更を加えるため に行われる作業は, 基本的に次の三つに分類すること ができる .

（1）ソフトウェア及びなされるべき変更の理解

( 2 ） ソフトウェアの変更

( 3 ) 変更後のソフトウェアの動作確認

このうち，(1) が正しく行われれば, 発見された欠 陥の原因を究明するために役立つ. 逆に, ソフトウェ アに対する理解がそしければ, 欠陥の原因究明及び訂 正に大幅な時間がかかる. 乥こでソフトウェアの理解 性及び保守性を向上させるための一手法としてソフト ウェア構成管理やリビジョン管理を行う方法がある．

ソフトウェア構成管理とはソフトウェア開発, 保守 過程で作成される, 樣々なプロダクトの識別や制御, 状 態の把握等を解決する作業を指す [5] . また , リビジョ ン管理とは開発チームが作成したプロダクト(ソー
スプログラムや付随する文書) に対する樣々な修正を 正しく認識し，組織化し，管理する作業であり，樣々 な管理手法のモデルが提案されている. 更に, 光のモ デルに基づくリビジョン管理システムが実装されてい る $[1],[16]$. 通常プロダクトの改訂は複数回行われ, 各 改訂ごとに作成されるプロダクトをリビジョンと呼ぶ

また，（3）を行うにあたり，ソフトウェアに変更を 加えた後で, ソフトウェアが仕樣どおりの性能で動作 するかどうかをテストするための一手法として回帰テ ストがある [6], [10], [13] . 回帰テストは実際のソフト ウェア保守において活用されており，修正が正しく行 われているかを検査する際に役立てられている .

\section{2 既存手法の問題点}

リビジョン管理システムを用いて開発されたソフト ウェアの保守段階では, 仕樣どおりの性能で動作する リビジョン (以下, 基準リビジョンと呼ぶ) が存在し ている . 従来のソフトウェア保守では, 上述した保守 作業の（2），（3) において, 基準リビジョンのプロ グラムを変更し, 回帰テストを用いてソフトウェアの 動作を確認している.

テストで欠陥が発見されれば，弚の欠陥の原因とな るエラーを取り除く (デバッグを行う) ために，保守 作業の $(1),(2)$ を繰り返し行う. しかし, 変更し ていない機能に欠陥が見つかった場合，光の原因とな るエラーを発見することは一般的に困難である .

乥こで, 基準リビジョンから現在のリビジョンに至 るまでの間に行われた修正を用いて自動的にテストを 行うことで, 欠陥の原因となるエラーを特定するため の研究が行われている [12], [17] . しかし , テストを行 うたびに, 基準リビジョンに変更を加えてコンパイル を行い，テストを適用するソフトウェアを作成するた め, テストに多大な時間が必要となる．また，准を 発見するたびに，弚の欠陥に応じてテストケースを逐 一作成する必要があるため, テストに利用しているテ ストツール [9] に関する教育や訓練も必要となる.更 には，欠陥の原因を特定するテスト作業にのみ重点が おかれており，弚の後のデバッグ作業までは考慮され ていないため, 実際の保守作業に关のままでは適用で きないといった問題がある .

\section{3. デバッグ手法 DMET}

本章では, 我々の提案する, リビジョン管理システ ムが保持しているプログラムの差分情報を用いた，回 帰テストを利用するデバッグ手法 DMET について述 
ベる .

\section{1 概 要}

DMET (Debugging METhod) は，基準リビジョ ンでは全機能が正常に働いており，保守作業の際に機 能に欠陥を作りこんだ場合のデバッグ作業を効率良く 行うことを支援するための手法である . DMET はテ スト手法, 表示手法, 反映手法という三つの手法を繰 り返し適用することにより，欠陥の除去を行う．

テスト手法では, テストツールを利用して自動的に テストを行い, 欠宿の原因を含むリビジョン間を特定 する. DMET では回帰テストを用いることにより，各 リビジョンが欠陥を含んでいるかを確認する . 回帰テ ストにおいて欠楩が発見された場合には, 弚の欠陥が どのリビジョンによって作りこまれたかを確認するた めのテスト (以降「局所化テス卜」と呼引゙）を行う .

表示手法では, テスト手法で特定された実行可能プ ログラムのリビジョン間の差分を, ソースプログラム の最新リビジョン上で表示する . 一般的にソースプロ グラムの修正作業は最新リビジョン上で行われるため， 特定されたリビジョンから最新リビジョンまでに行わ れた変更を, 本手法では自動的に求める.

反映手法では, テスト手法で特定されたリビジョン までリビジョンをさかのぼりながら, 最新リビジョン 上で修正作業時に行った変更を反映する . 本論文では 以降, 最新リビジョン上での修正変更を反映する必要 があるテストで欠陥を生じたリビジョンをまとめて 反映必須リビジョンと呼ぶことにする . 反映必須リビ ジョンに対して修正内容を適用することで, 弚れ以降 のテスト作業を効率良く続けることができる．

以下, 本手法が前提とするソフトウェア開発環境に ついて述べた後, テスト手法, 表示手法, 及び反映手 法の具体的手順について説明する .

\subsection{DMET を適用する際の前提環境}

ソフトウェア保守において我々の考えるデバッグ手 法を利用する際に, ソフトウェア及び炎の開発と保守， ソフトウェア保守担当者に必要となる前提条件につい て述べる．ある程度成熟したオープンソースソフト ウェアの開発事例など , この種の前提は広く普及して いる.よって我々は, これらの前提条件が近年のソフ トウェア開発環境で問題とはならないと考えている .

・リビジョン管理システムを用いた開発を行う

開発中の作業履歴を比較的詳細な単位で把握する ために,リビジョン管理システムを用いた開発作業を 前提とする.リビジョン管理の対象としては, ソフト
ウェアのソースプログラム , コンパイル済みファイル とする .コンパイル斎みファイルをリビジョンとして 登録する際には, 付随情報として当該ファイルとソー スプログラムのリビジョンの関連も記録する .

・ 基準リビジョンが存在する

本手法はソフトウェアの保守作業を対象としている . このため, 保守作業が開始される時点でのソフトウェ アを基準リビジョンとすることにより，修正前の全機 能が必ず動作することが保証されているリビジョンが 必ず存在することとする .

- 入力に対して何らかの出力を行う

本手法では，テストツールを用いてテストデータの 入力に対して出力が正しいものであるかを判定してい るため, 出力が行われるソフトウェアを対象とする . ここで出力とは, 例えば端末への文字列の出力等, 一 般的に目に見える結果として出されるものを仮定する．

- 入力や利用環境等は変更されない

一般的に , ソフトウェア保守活動においては規模の 大きな仕樣変更等は行われないため, 本手法では, 入 カパラメータ自体か増減するなどといった , ソフトウェ アに対する入力が変更されることは想定しない，また， 同樣の理由から，ハードウェアや動作環境といった， ソフトウェアの利用環境についても変更は行われない ことを本手法は前提とする.

このようなソフトウェア開発環境においては, 開発 者は小さな作業単位で光の結果をリビジョン管理シス テムに登録することが一般的である.一人の開発者が 小規模の開発を行っている場合，リビジョン登録を行 うたびに回帰テストを実行することも可能であろうが，

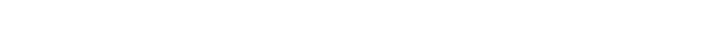
作業を行っており，また一人の作業者も同時に複数の 作業を並行して行うことも珍しくはない．また，ある まとまった作業の途中経過を記録するために, 修正が 不完全なものをリビジョンとして登録することもよく 行われる．このような状況においては, 開発者がリビ ジョン登録を行うごとに回帰テストを実行しても意味 がないため，ある程度まとまった作業が終了した時点 で, 修正が正しく行われたかを回帰テストなどによっ て確認することとなる

\section{3 テスト手法}

テスト手法では, ソフトウェアに対して何らかの変 更を行うたびに，用意されたテストをすべて実行する 回帰テストを自動的に行う.

テスト対象となるソフトウェアに対して用意された , 
完全化保守を行うために用いるテストの集合を $T_{1}$ 〜 $T_{n}$ とする .これらのテストは, 保守作業が開始され る際にあらかじめ用意する . また，あるファイルに対 する $i$ 番目のリビジョンを $V_{i}$ としたとき，基準リビ ジョンは $V_{B}$, 最新リビジョンは $V_{L}(B \leq L)$ として 表すものとする .いま，ある時点のソフトウェアに対 してテスト $T_{i}(1 \leq i \leq n)$ を適用する場合を考える． まずあらかじめ, 各ファイルについて正しく動作する ことがあらかじめ分かっている $V_{B}$ に対して,$T_{i}$ の入 カである $I_{i}$ を与えた場合の出力結果 $O_{B, i}$ をこのソ フトウェアの正常出力とする.

テスト手法ではまず， $V_{L}$ に対してすべての $T_{i}(1 \leq$ $i \leq n)$ を適用し, 光の出力 $O_{L, i}$ が $O_{B, i}$ と一致する かを確認する．もし，あるテスト $T_{i}$ を適用した際に欠 楩が発見された場合，局所化テスト $\operatorname{LclT}(i, L-1, L)$ を行う.

なお，局所化テスト $\operatorname{LclT}(i, j, k)$ とは, $V_{j}(j \leq k)$ に対して $T_{i}$ を適用した結果を判定し, かつ欠陥の原 因がどのリビジョンとどのリビジョン間に存在してい るかを返すテストである (図 1).ただし，ここでは $V_{k}$ に対して $T_{i}$ を用いてテストを行った際, 兴の出力 $O_{k, i}$ が $O_{L, i}$ と同一であることが分かっている . 局所 化テスト $\operatorname{Lcl} T(i, j, k)$ のアルゴリズムを図 2 に示す .

（1） j が基準リビジョン B と一致しているならば， $\left\ulcorner\right.$ 欠陥は $V_{B}$ と $V_{k}$ 間に存在する」と判断して終了する .

(2) $V_{j}$ に対し , テスト $T_{i}$ を適用する . 具体的に は, $I_{i}$ を $V_{j}$ に与えて, 出力 $O_{j, i}$ を得る.

(3) $O_{j, i}$ と $O_{k, i}$ が一致すれば, リビジョン $\mathrm{j} に$ はまだ欠陥が存在していることになるため, テストの 実行結果は「X」(同一の欠陥が含まれる) と判定す る.更に再帰的に $\operatorname{LclT}(i, j-1, j)$ を実行し，光の結 果を求める結果とする.

（4）もし $O_{j, i}$ と $O_{B, i}$ が一致した場合には,リビ ジョン $\mathrm{j}$ の時点では欠陥が含まれていなかったことに なるため, テストの実行結果は「○」(欠陥が含まれ

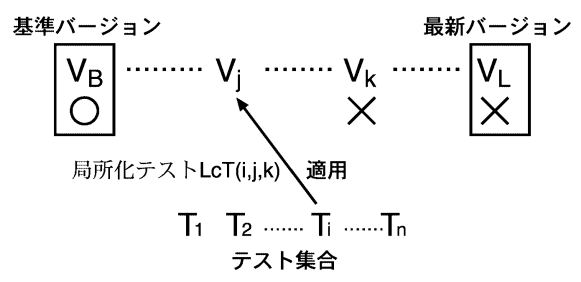

図 1 局所化テスト

Fig. 1 Localization test.
ない）と判定する．また，「欠陥は $V_{j}$ と $V_{k}$ 間に存在 する」と判断して終了する．

（5）光れ以外の $O_{j, i}$ 自体か得られた場合には，テ ストの実行結果は「一」(新たな欠楩が発見された) と 判定する.また，実行結果がソフトウェアの異常終了 のため得られなかった場合には「 $\triangle 」($ 結果が得られ ない) であったとする．どちらの場合においても，更 に再帰的に $L c l T(i, j-1, k)$ を実行し，弚の結果を求 める結果とする .

本手法では, 各リビジョンを新しいものから順に線 形探索を行うことにより，准を含む個所の特定を 行っている．仮に結果が「○」と「メ」しかなく，か つ，○から×への遷移がたかだか 1 回しか起きない場 合には，二分探索を用いることによりより効率の良い 探索が可能である.しかし，前提として光の他の出力 が含まれる場合や，何らかの理由により○から×，あ るいは关の逆への遷移が複数考えられるため，ここで は二分探索を用いることはできない .

\section{4 表示手法}

テスト手法で発見したリビジョン間の差分(こ こでは,リビジョン C とリビジョン E の間とする

局所化テスト: $\operatorname{LCIT}(\mathrm{i}, \mathrm{j}, \mathrm{k})$

\begin{tabular}{|c|c|}
\hline $\mathbf{V}_{\mathbf{i}}$ : テストパージョン $\mathbf{T}_{\mathrm{i}}$ : テスト & $\mathbf{O}_{\mathrm{j}, \mathrm{i}}$ :テスト出力 \\
\hline $\mathrm{V}_{\mathrm{k}}$ : 欠陥バージョン $\mathrm{l}_{\mathrm{i}}$ : テストスカ & $\mathbf{O}_{\mathbf{k}, \mathbf{i}}\left(=\mathbf{O}_{L, i}\right):$ 欠陥出力 \\
\hline & $\mathbf{O}_{\mathrm{B}, \mathrm{i}}$ : 正常出力 \\
\hline
\end{tabular}

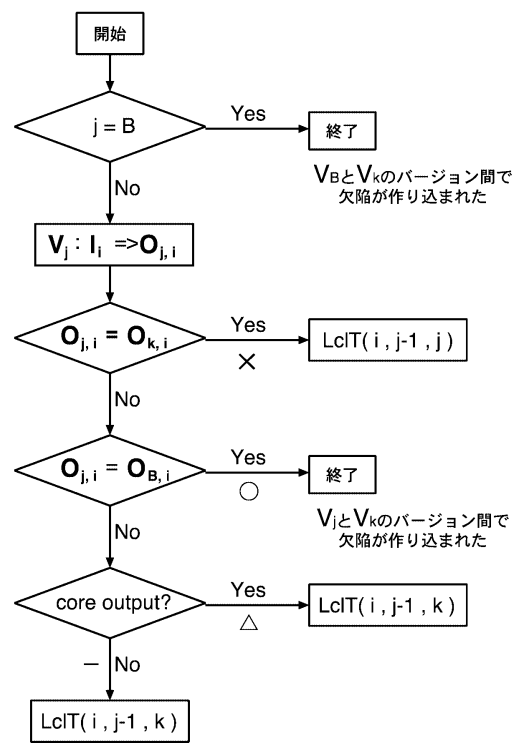

図 2 局所化テストアルゴリズム

Fig. 2 Localization test algorithm. 
$(C<E \leq L))$ を最新のリビジョン L で表示するた めに, まずソフトウェアとソースプログラムの関連情 報を利用して , どのソースプログラムのどのリビジョ ン間の差分を強調表示するか調べる . 両リビジョン間 で削除された場合，あるいは挿入された場合に応じて， 以下のような表示を行う.

[削除] 現在リビジョンのソースプログラム上に現れ ず, 変更前のソースプログラム自身は強調表示できな い (図 3 参照).このため, 最新リビジョン上では, 削 除されたソースコードの場所と内容を示す印によって 強調表示を行う (図 $2 V_{L}$ における点線表示).

[挿入 ] 現在リビジョンのソースプログラム上に現れ る部分を強調表示する (図 4 参照). 挿入後にも何ら かの変更が行われるが, 欠陥の致命的な原因となる部 分は変更されていないと考えられる.

\section{5 反映手法}

局所化テストで新たな欠陥が発見された場合，まず その欠陥の除去を最新リビジョン L に対して行う (以 下，これをした差分を修正 $\Delta L$ と呼ぶ）．次に，局所 化テストを続行するために， $\Delta L$ を過去のリビジョン に反映させる．まず，patch プログラム等を用いて， $\Delta L$ を過去のリビジョンへ適用し, 新たなソフトウェ アを作成すべくコンパイルを行う．もしコンパイルが 成功すれば, 光れを新たなテスト対象プログラムとし て利用する．もし $\Delta L$ の patch が失敗するか, 成功 してもコンパイルに失敗した場合には, 弚のリビジョ ンは以降の回帰テストの対象外とする .

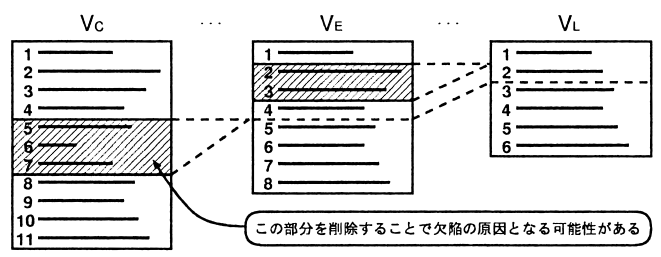

图 3 リビジョン間の差分でコードを削除した場合 Fig. 3 Code deleted between revisions.

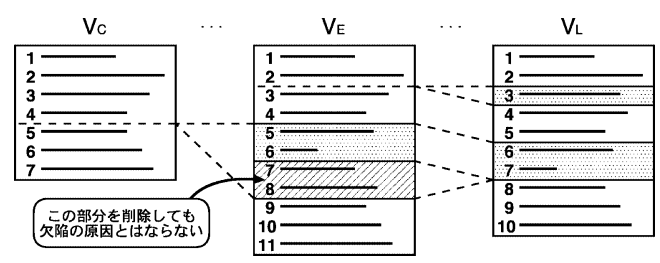

图 4 リビジョン間の差分でコードを挿入した場合 Fig. 4 Code inserted between revisions.

\section{4. 評 価 実験}

本章では, DMET に基づくデバッグ支援システム DSUS を用いた，DMET の評価実験について述べる .

\section{1 試作システム DSUS}

DMET に基づくデバッグ支援システムの構築にあ たり，我々は以下の点に留意してシステムの作成を 行った.

・プログラミング言語から独立

一般的に , プログラミング言語に依存したシステムを 構築することによって, より細かいデバッグ支援を行 うことが可能になる.しかし, 現在のプログラミング 開発は多くのプログラミング言語によって行われてお り，DMET 自身は言語に依存しない手法であること から，DSUS には特定のプログラミング言語に依存し た機能をもたせないようにした .

・ テストとエラー修正の両方を支援

DSUS はテストの自動実行だけでなく，テストによっ て発見したエラーの修正を行うための環境を提供する これによって，開発作業をDSUS 内で完結させること ができる .

- ツールの自動実行

テストの実行をはじめ, DMET で述べられている各 作業を順次正しく実行することは, 開発者に対して更 なる負担を強いることになる可能性がある.DSUS で は，DMET の手順や弚れに付随するテストを自動的 に行うことによって，DMET の導入にかかる負担を 減らすことを目指す。

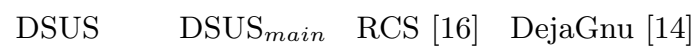
と，ユーザに対する GUI から構成される（図 5)。 GUI を用いることにより, ソースコードの編集やエ ラーを含むと考えられる差分の表示などを行う .

$\mathrm{RCS}$ は, 多くの開発環境で用いられている, リビ ジョン管理システムである. DSUS は, ユーザがRCS に対する操作のインタフェースとして動作することに より, 誤つた操作や危険な操作を行わないように作ら れている．また，開発者がンースコードを編集する際 には，定期的に弚の内容を RCS 登録することによっ て， RCS に登録される差分が小さくなるようにする． DejaGnu はオープンソースで開発が進められている テスト実行フレームワークであり, DSUS では回帰テ ストを実行するために用いられる .

DSUS $_{\text {main }}$ は DSUS 全体の中核をなす部分である GUI の管理, RCS に対する操作, DejaGnu 実行環境 
の設定やテストの管理はこの部分で行われる . DSUS の GUI (図 6) は, 大きくエディタ用ウィンドウ (画 面左) と状態ウィンドウ (画面右) から構成される . 開発者は，状態ウィンドウから選択することにより， 任意のリビジョンのソースコードを取り出して編集す ることができる．また，画面上部のボタンを利用して， テストの実行等を指示することができる . テストの結 果, エラーが検出された場合には, エラーが含まれる と考えられるリビジョンを色付きで表示する .

DSUS は C 言語によって実装されており，規模は約 20000 行である.また，GUI の実装には GTK＋を用

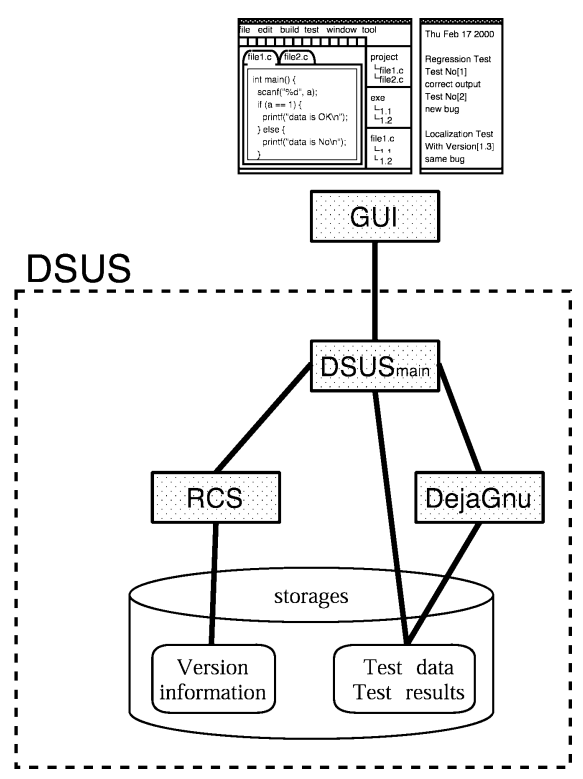

図 5 DSUS の構成

Fig. 5 The DSUS structure.

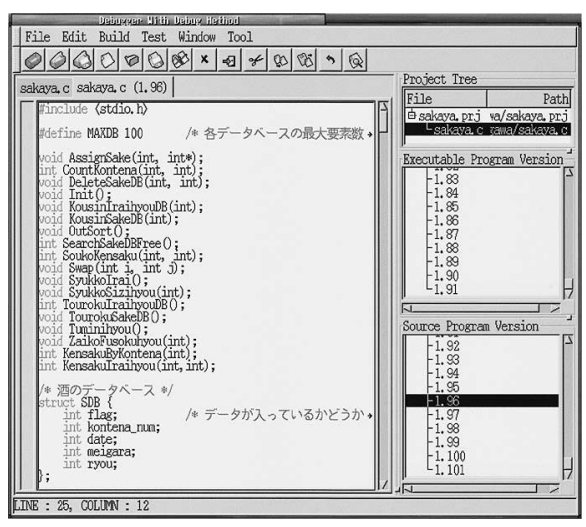

図 6 DSUS の GUI 画面

Fig. 6 Screenshot of GUI.
いた .

\section{2 実験の概要}

デバッグ作業を DMET に従った場合と従来手法で 行った場合でかかる時間にどの程度の差が見られるの かを, DSUS を用いて調べ, 本手法の実用性を示す．

本実験では，Cプログラミングの経験をある程度も つ大学 4 年生及び大学院生 10 人を被験者とした . 全 体を二つのグループ $\left(G_{1}\right.$ と $\left.G_{2}\right)$ に分け, グループ $G_{1}$ は DSUS を, グループ $G_{2}$ は, DSUS の機能のう ち, DMET に基づくリビジョンの特定機能のみを利 用できないようにしたDSUS を用いて，デバッグ作業 を行うこととする．なお，デバッグ対象として用いる ソフトウェアの問題としては, 酒屋問題 $[8]$ を用いた .

実験は , ステップ 1 とステップ 2 に分け , ステップ 1 で, ステップ 2 の際に用いるデバッグ対象となるソ フトウェアの開発と収集を行った，収集されたソフト ウェアを用いて，本実験でデバッグ作業を行った．

\section{3 ステップ 1}

酒屋問題のうち「空コンテナマーク」部分以外を正 しく実装したソフトウェアを事前に用意しておき，こ れに対して，空コンテナマークの機能を追加する．な お，当該ソフトウェアは $\mathrm{C}$ 言語で記述されており，お よ光 500 行程度の規模である. 得られたソフトウェア のうち，この拡張により他の機能に対して欠陌を生じ るようになった二つのソフトウェア (以下 , ソフトウェ ア A ， B) をステップ 2 でデバッグ対象とするソフト ウェアとした . 表 1 に収集したソフトウェアの一覧と 弚の開発履歴を示す。

例えばソフトウェア A は, 最初に用意したソフト ウェアを初版として合計 28 のリビジョンをもつ .ソフ トウェア A は, DMET によって 25 回の局所化テス トが実行され, 光の結果 DMET が検出したリビジョ ン間の差分に, 欠楩が含まれていることが分かった .

\section{4 ステップ 2}

グループ $G_{1}$ 及び $G_{2}$ に対して , ステップ 1 で得ら れた三つの欠陥を含むソフトウェアを与え, DSUS を 用いてデバッグ作業を行ってもらった . デバッグの際 に利用するテストデータについては，あらかじめ準備

表 1 本実験で用いたソフトウェアの開発履歴

Table 1 Development software and its history.

\begin{tabular}{|c|c|c|}
\hline ソフトウェア名 & リビジョン数 & テスト回数 \\
\hline $\mathrm{A}$ & 28 & 25 \\
\hline $\mathrm{B}$ & 91 & 10 \\
\hline
\end{tabular}


表 $2 G_{1}$ のデバッグ時間 (DMET 利用)

Table 2 Debugging time of $G_{1}$. (with DMET)

\begin{tabular}{|c|c|}
\hline 被験者 & 平均 $($ 分 $)$ \\
\hline $\mathrm{T} 1$ & 75 \\
\hline $\mathrm{T} 2$ & 62 \\
\hline $\mathrm{T} 3$ & 65 \\
\hline $\mathrm{T} 4$ & 79 \\
\hline $\mathrm{T} 5$ & 54 \\
\hline $\mathrm{G} 1$ 全体 & 67.0 \\
\hline
\end{tabular}

表 $3 G_{2}$ のデバッグ時間 (DMET 非利用)

Table 3 Debugging time of $G_{2}$. (without DMET)

\begin{tabular}{|c|c|}
\hline 被験者 & 平均 $($ 分) \\
\hline $\mathrm{T} 6$ & 237 \\
\hline $\mathrm{T} 7$ & 107 \\
\hline $\mathrm{T} 8$ & 237 \\
\hline $\mathrm{T} 9$ & 69 \\
\hline $\mathrm{T} 10$ & 165 \\
\hline $\mathrm{G} 2$ 全体 & 163.0 \\
\hline
\end{tabular}

したものを用いてもらい, 与えたテストデータに対す る処理が正しく行えるのを確認できた時点でデバッグ 終了とした .デバッグを開始してから終了するまでの， 各被験者が費やした時間の計測を行った . 表 2 と表 3 が, 実験によって得られた各被験者（T1〜 T10）のデ バッグ時間である (単位は分) .

\section{5 考察}

ソフトウェア A , B のデバッグ時間合計に対して , $5 \%$ 有意水準による Welch の検定を用いたところ， $G_{1}$ と $G_{2}$ には有意な差が見られることが確認できた . 本 実験により，DMET を用いることによってデバッグ 時間を短縮することができることが分かった .

\section{5. 関 連研 究}

本章では，これまでに行われてきた欠陥の原因とな るエラーを特定するための手法に関する研究について 取り上げ，既存の手法が抱える問題点について述べる.

\subsection{Ness と Ngo の研究}

Ness と Ngo はグレイ研究所において, コンパイラ 開発のために regression containment と呼ばれる手法 を利用している [12] . Ness らの手法では, まず回帰テ ストを自動的に行う.この回帰テストが失敗した場合， 基準リビジョンが正しく動作することに着目して, 構 成管理から取得した修正を実際の適用順に施しながら テストを繰り返し行う.テストが失敗した段階で觉の ときに適用した修正をバグの原因となるエラーとして 特定する。

しかし, Ness らの手法は特定の状況ではうまく動
作するが , 単一の差分だけではなく複数の差分が適用 されることで初めてテストが失敗する場合や, 変更の 適用によりコンパイルできないといった矛盾が生じる 場合にはうまく動作しない .

\subsection{Zeller の研究}

Zeller は Ness らの問題点である複数のエラーによ る欠陥や変更の適用による矛盾にも対応可能な手法を 提案している $[17]$. Zeller の手法では，修正を適用す る場合の順序は考慮せず, 修正を集合の一要素として とらえる.したがって, 行われた修正の数が $n$ であれ ば, 考えられる集合の数が $2^{n}$ となる. Zeller は考え られる集合の中から欠陥が生じる要素数が最小の集合 を見つけ出すアルゴリズムを利用する . 修正の集合を 利用することで, 複数のエラーによって引き起こされ る欠陥の原因を特定することに成功している．また， 変更の適用による矛盾にも対応できるアルゴリズムで あり，Ness らの手法では見つけることができなかった エラーも発見することができる．

しかし，アルゴリズムを複雑にすることでバグの原 因となる差分を特定する精度は上がるが, 修正の数に 対して指数的にテストすべき集合の数か増加する.し たがって, テストの回数が増加し, テストに多大の時 間がかかる。

\section{3 問 題 点}

Ness らと Zeller のどちらの手法も基準リビジョン のソースプログラムを基本として考えており, テスト を行うためには毎回兴のソースコードに修正を適用し て , コンパイルを行わなければならない . また，どの ソースプログラムをどのように修正したかを正確に管 理した上でコンパイルを行う必要があるため, 単純に コンパイルを行うだけでも繁雑な作業となる．

また，㫿の原因を探るために自分でテストケース を作成してテストを行う必要があり，各々の手法で利 用しているテストツールの学習や訓練を行わなければ

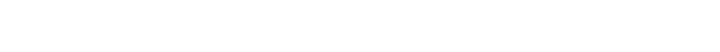
卜作業にのみ重点がおかれており，デバッグ作業まで は考慮されていないため, 実際の保守作業に適用する ことは難しい .

DMET では, どのソースプログラムをどの時点で コンパイルすることになるか，をDMET 自体の枠組 みで管理することになり，DSUS のような支援環境を 用いることによって容易にコンパイル作業を行うこと が可能となっている．また，DMETにおいては最初 にテストケースを作成しておき，乥れを用いたデバッ 
グを行うため，欠陥に応じてテストケースを自作する 必要性がなく，またテストケース作成自体にかかる時 間も軽減される．DMET は欠陥の特定だけではなく， デバッグ作業まで含めた作業を対象としているため， 実際の保守作業においても容易に適用することが可能 であり，今回実験によって关れを示している。

\section{6. むす び}

本研究では, 保守作業を対象としたデバッグ手法 DMET の提案を行った . また , 試作システムDSUS を用いた実験を通じ，DMET の有効性を示した．本 手法を用いることで, 実際の保守においてデバッグ作 業をより行いやすくなることが期待できる．

今後の課題としてまず, 差分検出アルゴリズムの改 良によって，缏の含まれる差分の検出をより確実に 行うことが挙げられる．また, DMET が検出した差 分か比較的大きくなった場合, DMET によって得られ た結果を用いても作業時間の短縮に貢献しないことが 考えられる.このような場合, DSUS があらかじめ氒 れを判断し, 単に結果を提示するだけではなく, 開発 者に注意するための方法などについて検討を行いたい．

$$
\text { 文献 }
$$

[1] W.A. Babich, Software Configuration Management, Addison-Wesley, Reading, MA, 1986.

[2] CASE 1988-89, Sentry Market Research, Westborough, MA, pp.13-14, 1989.

[3] M. Carma (著), ベスト CASE 研究グループ (訳) , ソ フトウェア開発と保守の戦略, 共立出版, 1993.

[4] P.M. Cashman and A.W. Holt, "A communicationoriented approach to structuring the software maintenance environment," Software Engineering Notes, vol.5, no.1, pp.4-17, Jan. 1980.

[5] R. Conradi and B. Westfechtel, "Version models for software configuration management," ACM Computing Surveys, vol.30, no.2, pp.232-280, 1998.

[6] T. Dogsa and I. Rozman, "CAMOTE - Computer aided module testing and design environment," Proc. Conference on Software Maintenance - 88, pp.404408, Phoenix, AZ, 1988.

[7] W. Hetzel, The Complete Guide to Software Testing, in QED Informaion Sciences, Wellsley, MA, 1984.

[8] H. Kudo, Y. Sugiyama, M. Fujii, and K. Torii, "Quantifying a design process based on experiments," Proc. 21th International Conference on System Sciences, pp.285-292, Hawaii, 1988.

[9] IEEE, "Test Methods for Mesureing Conformance to POSIX," ANSI/IEEE Standard 1003.3-1991, ISO/IEC Standard 13210-1994.

[10] H.K.N. Leung and L. White, "Insights into regression testing," Proc. Conference on Software Maintenance 89, pp.60-69, Miami, FL, Oct. 1989.

[11] B. Lientz and E. Swanson, Software Maintenance Management: A Study of the Maintenance of Computer Application Software in 487 Data Processing Organizations, pp.151-157, Addison-Wesley, Reading, MA, 1980.

[12] B. Ness and V. Ngo, "Regression containment through source code isolation," Proc. 21st Annual Internatial Computer \& Applications Conference (COMPSAC '97), pp.616-621, IEEE Computer Society Press, 1997.

[13] B. Raither and I. Osterweil, "TRICS: A testing tool for C," Proc. First European Software Engineering Conference, pp.254-262, Strasbourg, France, 1987.

[14] R. Savoye, Test DejaGnu testing framework for DejaGnu version 1.3, Free Software Foundation, Jan. 1996.

[15] E. Swanson, "The dimensions of maintenance," Second International Conference on Software Engineering Proceedings, San Francisco, pp.492-497, Oct. 1976.

[16] W.F. Tichy, "RCS - A system for version control," Software-Practice and Experience, vol.15, no.7, pp.637-654, 1985.

[17] A. Zeller, "Yesterday, my program worked. Today, it does not. Why?," Proc. 7th European Software Engineering Conference and 7th ACM SIGSOFT International Symposium on the Foundations of Software Engineering (ESEC/FSE '99), pp.253-267, Toulouse, France, Sept. 1999.

(平成 15 年 6 月 26 日受付, 16 年 1 月 6 日再受付)

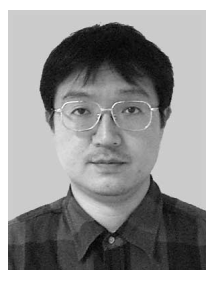

松下誠

平 5 阪大 · 基礎工 ・ 情報卒. 平 10 同大 大学院博士後期課程退学. 同年同大 · 基礎 工学研究科・助手. 平 14 同大 ·情報科学研 究科・助手. 博士 (工学) . ソフトウェア開 発環境, ソフトウェア開発プロセス, オー プンソース開発の研究に従事 .

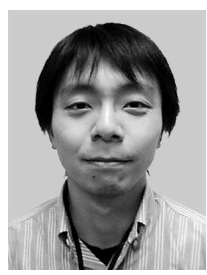

\section{寺口 正義}

平 5 阪大 · 基礎工 ·情報卒. 平 12 同大 大学院博士前期課程了. 同年 IBM 基礎研 究所. 修士 (工学). 在学時, デバッグ支援 環境の研究に従事. 


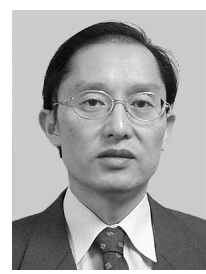

井上 克郎 (正員)

昭 54 阪大·基礎工 ·情報卒 . 昭 59 同 大大学院博士課程了. 同年同大 $\cdot$ 基礎工 . 情報・助手. 昭 59〜昭 61 ハワイ大マノア 校・情報工学科・助教授、平元阪大 $\cdot$ 基礎 工. 情報. 講師. 平 3 同学科・ 助教授. 平 7 同学科. 教授. 平 14 同大 $\cdot$ 情報科学研 究科・教授. 工博. ソフトウェア工学の研究に従事. 